\title{
IAMJ
}

INTERNATIONAL

AYURVEDIC

MEDICAL JOURNAL

\section{PAIN MANAGEMENT IN KATISHOOLA: A CASE STUDY}

\section{Kavita $^{1}$, Suresh N Hakkandi ${ }^{2}$, Manjunath $\mathrm{Akki}^{3}$, Guru Mahantesh $\mathrm{T}^{4}$}

${ }^{1}$ Final year PG Scholar Department of Panchakarma S.J.G Ayurvedic medical college Koppal, Karnataka, India ${ }^{2}$ Professor and HOD, Department of Panchakarma S.J.G Ayurvedic medical college Koppal, Karnataka, India ${ }^{3}$ Associate professor, Department of Panchakarma S.J.G Ayurvedic medical college Koppal, Karnataka, India

${ }^{4}$ Associate professor, Department of Panchakarma S.J.G Ayurvedic medical college Koppal, Karnataka, India

Corresponding Author: drkavitabs7@gmail.com

\section{https://doi.org/10.46607/iamj4509112021}

(Published Online: November 2021)

Open Access

(C) International Ayurvedic Medical Journal, India

Article Received: 25/10//2021 - Peer Reviewed: 05/10/2021 - Accepted for Publication: 06/10/2021

\section{Check for updates}

\section{ABSTRACT}

Lower Back Pain can have causes that aren't due to underlying diseases and this pain refers to the pain that usually begins in the lower back region, radiating to the sacroiliac regions and buttocks. ${ }^{[1]}$ People with chronic pain often find it difficult to cope with work, family and social activities which is the significant cause of disability worldwide. Eighty percent of the population is affected by this symptom sometimes in life. ${ }^{[2]}$ Increased prevalence of low back pain and temporary and reduced success rates in invasive contemporary treatment measures has drawn considerable attention towards alternative, effective, non-invasive treatment modalities. Katishoola, a Vata vyadhi diagnosed with cardinal symptoms as Pain in Kati Pradesha. In Ayurveda, a holistic approach has been adopted that includes the use of oral Ayurvedic formulations, Panchakarma procedures like Snehana karma (unction therapy), Swedana karma (sudation therapy) etc. ${ }^{[3]}$ Here In this article a case of low Back Pain treated with Kati Pichu with Masha taila with good outcomes are reported.

Keywords: Katishoola, Low Back Pain, Masha Taila, Kati Pichu 


\section{INTRODUCTION}

Science is an essential element of daily life flourishing continuous research and re-evaluations. Ayurveda assists individuals to take control of their own health and increase self-reliance and re-establishes their connection to the environment. Ayurveda literature always emphasized the need for advancements in science to keep pace with the need of time ${ }^{4}$ the pledged purpose of Ayurveda as a medical system is to ensure a healthy and long life for humanity which encourages certain lifestyle interventions and natural therapies to regain a balance between the body, mind, spirit, and the environment. The spine or backbone is our body's central support structure which plays a major role in mobility which is a basic character of life. A normal daily life without mobility is almost impossible for any individual. Among the backbones, the low back region or lumbar region has its own significance in maintaining the posture as the maximum bodyweight is being supported by this region. In the over elaborated professional and social life, improper posture creates pressure over the low back and turns daily life into misery. Low back pain has become a common medical condition, which is felt in everyone's life at one or the other time. Sometimes it needs medical concern to overcome it. The incidence of low back pain is rising day by day. It may affect the different age groups and disturb the routine work of an individual. It has become a key issue to resolve in day-to-day clinical practice. So, to find out the causative factors and to give relief from low back pain to an individual is the need of time. In Ayurveda, Katishoola can be correlated with low back pain. Katishoola is one such condition caused by vitiation of Vata characterized by pain, tenderness, and restricted movements of Kati Pradesha. Katishoola is not mentioned as a separate disease in Brihatrayees but the description of this may be traced in some other disorders like Kati graham, Prista graham which is included under Vatavyadhi. Even though it is not mentioned as a separate disease, some of the references suggest Katishoola as a symptom ${ }^{5,6}$, Snehana and Swedana are considered as a general line of treatment for Vata vyadhi which can be taken as a line of treatment for Katishoola also. Kati Pichu is one such treatment modality that comes under Snehana and Swedana and is known for its efficacy in relieving the symptoms. Masha taila due to its Vatahara and Shoolahar action has been taken for the case study ${ }^{7}$

\section{CASE REPORT}

A 32-year-old female patient (Registration No 101566), residing in Koppal, visited Panchakarma OPD of S J G Ayurveda Medical college \& Research centre, Koppal on $4^{\text {th }}$ February 2021, with complaints of pain and stiffness around the low back region of the body.

\section{Presenting Complaints}

The patient was having pain around the low back region for the last 2 years. For the last one month, the pain was aggravating; making her uncomfortable on prolonged sitting, standing, and bending forwards. There was a gradual onset of Intermittent radiation of pain on the right thigh was also reported. She also had a decreased bowel clearance for a long time. There was no history of any trauma. However, being a therapist, she had to stand and work for around 6-7 hours a day. She had a history of taking allopathic treatment from several private hospitals. From that, she got some temporary relief for a few days. For the last one month, her symptoms got aggravated and she visited Panchakarma OPD of S J G Ayurveda Medical College \& Research Centre, Koppal for the better treatment of her condition.

\section{History}

There was no history of any other acute or chronic ailment. No history of Diabetes Mellitus, Hypertension, Tuberculosis, Asthma, Jaundice or Covid 19 infection. As such no history of any surgical intervention in the past was reported.

\section{Clinical Examination}

She was thoroughly examined locally as well as systemically. The general condition of the patient was stable, fully conscious, and well oriented. The vitals were found to be within normal limits. Her blood pressure was $110 / 80 \mathrm{~mm}$ of $\mathrm{Hg}$ level, Pulse Rate was $80 / \mathrm{min}$, and body temperature was $98.2^{\circ} \mathrm{F}$. Her body height was five feet and 4 inches, and her body 
weight was $60 \mathrm{~kg}$. Cardiopulmonary status was found normal. Chest expansion was normal. Findings of Ashtavidha Rogi Pareeksha were

Nadi: Vata pradhana,

Jihva: Sama,

Mala: Vibandha,

Mutra: Samyak Pravrutti,

Shabda: Spashta, Prakruta

Sparsha: Asahishnuta

Drika: Prakruta and

Akriti: Madhyama.

Local examination of the spine revealed straightening of lumbar curvature, no bony tenderness could be elicited, no swelling, no scar was observed. The local temperature was found to be normal. The range of movements was found to be compromised due to acute pain. The femoral Nerve Stretch Test was found negative bilaterally. Fabers test and Pump handle test were also found negative to exclude the involvement of pathology related to sacroiliac joints. A bilateral motor power test was done for extensor hallucis longus and was found to be normal. Sensations on all the dermatomes were found to be bilateral normal and equal. Deep tendon reflexes were checked. Knee jerk: bilateral normal (++), Ankle jerk was decreased $(+)$ on the left side and Babinski's reflex was checked bilaterally and found absent.

\section{Laboratory Investigations}

All the routine blood investigations, Random Blood Sugar (RBS) levels and Erythrocyte Sedimentation Rate (ESR) were carried out and were found to be within normal limits. Routine and microscopic urine analysis was also found normal

\section{Plan of Management}

The patient was advised to come for the treatment under the department of Panchakarma at SJGAMAC Koppal, Karnataka, India. She was managed by the Department of Panchakarma of the institute for the procedure of Kati Pichu (procedure of keeping warm medicated oil at low back region). For this treatment procedure, Masha Taila was used and advised to be done once a day, for about 45 minutes for the total duration of 07 days.

\section{OBSERVATION}

\begin{tabular}{|l|l|l|l|}
\hline S. No. & Criteria & Before Treatment & After Treatment \\
\hline 1 & Pain Intensity & $\begin{array}{l}\text { Pain was severe } \\
\text { (Score 3) }\end{array}$ & The pain was very mild now(Score 1) \\
\hline 2 & $\begin{array}{l}\text { Personal care } \\
\text { (washing, } \\
\text { Dressing etc.) }\end{array}$ & $\begin{array}{l}\text { The patient needed help eve- } \\
\text { ry day in most aspects of } \\
\text { self-care (Score 4) }\end{array}$ & $\begin{array}{l}\text { The patient was able to look after herself normally without caus- } \\
\text { ing pain (Score 1) }\end{array}$ \\
\hline 3 & $\begin{array}{l}\text { Lifting } \\
\text { Weight }\end{array}$ & $\begin{array}{l}\text { The patient could lift very } \\
\text { light weights (Score 4) }\end{array}$ & $\begin{array}{l}\text { The pain was preventing her from lifting heavy weights but was } \\
\text { able to manage light to medium weights if they are conveniently } \\
\text { positioned (Score 3) }\end{array}$ \\
\hline 4 & Walking & $\begin{array}{l}\text { The patient took 50 seconds } \\
\text { to cover 21 meters (Score 4) }\end{array}$ & $\begin{array}{l}\text { The patient was able to walk 21 meters in 30 seconds } \\
\text { (Score 1) }\end{array}$ \\
\hline 5 & Sitting & $\begin{array}{l}\text { The pain prevented her from } \\
\text { sitting for more than 20 } \\
\text { minutes (Score 3) }\end{array}$ & $\begin{array}{l}\text { The pain was preventing her from sitting more than one to two } \\
\text { hours (Score 2) }\end{array}$ \\
\hline 6 & Standing & $\begin{array}{l}\text { The pain was preventing her } \\
\text { from standing at all (Score 5) }\end{array}$ & $\begin{array}{l}\text { She could stand if she could, but it was causing her extra pain } \\
\text { (Score 1) }\end{array}$ \\
\hline
\end{tabular}

\section{Range of Movements}

Before treatment the movements of the spine particularly the flexion and extension were painful and compromised. After treatment, they were found to be

within normal range and without pain.

\section{Follow up Advice}

The patient was advised regular exercises of the back region. She was given instructions to maintain a 
proper posture of the spine while working, to avoid forward bending and weightlifting, to avoid prolonged standing and sitting. Her occupation was demanding prolonged standing for the work, so she was advised to sit and to take a rest after every one hour. Plenty of fluids and a fibre-rich diet was advised to her to have a normal bowel clearance. Capsule Cervilon 2 times with warm water and Capsule Nuro-XT 2 times with warm water was continued for 15 days more.

The patient visited after 15 days. No recurrence of symptoms was noticed. All the medications were stopped, and she was advised back exercises and instructions related to diet and body posture.

\section{DISCUSSION}

In Ayurveda, Shoola (Pain) is said to be produced by vitiated Vata Dosha. ${ }^{[8]}$ Kati (Low Back Region) includes the Dhatus (Structural and functional components) like Asthi (Bones), Sandhi (Joints including intervertebral discs) and supporting structures like Mamsa-Peshi (muscles) and Snayu (ligaments) etc. along with the Srotasa (Channels of circulation). Katishoola is the condition where due to vitiated Vata, symptoms like pain and stiffness get Sthana samshraya in Kati Pradesha Kati has been described as the main seat of Vata Dosha. The management principle of Vitiated Vata includes several management tools like oral Ayurvedic medicines, Snehana including Abhyanga (unction by massage), Swedana (sudation). As such Snehana and Swedana have been advised to be used repeatedly in the patients suffering from Vata Roga (diseases caused by vitiated Vata) by Acharya Charaka. ${ }^{[9]}$

In Kati Pichu, comfortably warm oil is retained in the low back area that exerts a direct local Snehana (unction) and Swedana (sudation) properties thereby alleviating the vitiation of VataDosha, resulting in relief from pain and muscle spasm, stiffness. ${ }^{[10]}$

\section{Discussion on Mode of action of Kati Pichu}

Kati pichu procedure is evolved from Shiro pichu and it is a kind of Bahya snehana and swedana procedure. Snehana and swedana mainly act against the ruksha and Shita guna of vata. Sushruta explains that out of four tiryak dhamanis, each dhamani divides into hundred and thousand times and become innumerable. These dhamani form a network and spread all over the body. They have their openings in the Loma koopa. The dravya applied over the skin is absorbed through these openings and undergo pachana with the help of pachaka pitta which is situated in the skin.

The vata dosa is the key factor in the causation of Katishoola. The properties of Masha taila such as snigdha, guru, usna are opposite to the properties of vata.

\section{Drug absorption}

The principal site for absorption of exogenous material through the skin is stratum corneum. The pace of absorption is directly proportional to the concentration of drug in-vehicle, partition coefficient, diffusion coefficient and thickness of the stratum corneum. The physiological factors that affect percutaneous absorption include hydration, occlusion, age, intact versus disrupted skin, temperature, and anatomical site.

Absorption depends upon the lipid solubility of the drug since the epidermis act as a lipid barrier. The dermis however is freely permeable to many solutes. Suspending the drug in an oily vehicle can enhance absorption through the skin. Because hydrated skin is more permeable than dry skin.

\section{Effect of application of heat}

The application of heat in the different forms of swedana promotes local circulation and metabolic activities and opens the pores of the skin to permit the transfer of medicaments and nutrients towards needed sites and elimination of vitiated dosa and mala through skin and perspiration.

The application of heat on skin induces increased metabolic activity, increased circulation, and stimulation of nerve endings on skin and tissues. The metabolic activity is increased in the part where more heat is applied. This increased metabolism creates a demand for oxygen and nutrients. The heat applied has a direct effect on the blood vessels which cause them to dilate and increase the amount of blood circulation. The applied heat also stimulates the 
nerve endings which causes reflux dilation in the arterioles. Due to all these reasons, the blood circulation is increased, and the active ingredients of the drug are supplied to the target cells.

\section{CONCLUSION}

Low Back Pain (Katishoola) is a Vata predominant disease. Low back pain is having a high prevalence, especially in the elderly and a high rate of disability due to the diseases makes it a leading problem in the elderly and nowadays it is becoming common in the adult group also. Its Ayurvedic management includes oral medications and Panchakarma procedures that have Vedana Sthapana (analgesic), Shothahara (antiinflammatory) and Rasayana (rejuvenation and immunomodulator) properties. Ayurveda can help in the management of low back pain by alleviating the symptoms of the disease and improving the quality of life of the patient. However, it depends upon the selection of patients and the availability of Ayurvedic medical facilities. Concomitant instructions related to rest, posture, physiotherapy (back exercises), diet and lifestyle modifications are also useful to the patient and should always be advised.

\section{REFERENCES}

1. S. Terry Canale, James H. Beaty: Campbell's Operative Orthopedics, Volume Two, Chapter 42-Lower Back Pain and Disorders of Intervertebral Discs. 12 $2^{\text {th }}$ Edition (International Edition), Elsevier Mosby Publications, Philadelphia, 2013s; 1935.

2. John Ebnezar: Textbook of Orthopedics, Chapter 34Low Backache and Repetitive Stress Injury (RSI). $4^{\text {th }}$ Edition, Jaypee Brothers Medical Publishers (P) Ltd. New Delhi, 2010; 461.

3. Dr Indradeva Tripathi: Chakradatta of Shri Chakrapani Datta, Chapter on Vatavyadhi Chikitsa verse no.76, Edition Reprint, Chaukhambha Sanskrit Bhawan, Varanasi, 2014; 140.

4. https://www.internationalhealthpolicies.org

5. Pandit Kashinath Shastri and Dr Gorakhnath Chaturvedi, Charak Samhita of Agnivesa, Chikitsa sthana, chapter no-14, shloka no-11, Varanasi, Chaukhambha Bharati Academy, Reprint-2015, Page no-421.

6. Pandit Kashinath Shastri and Dr Gorakhnath Chaturvedi, Charak Samhita of Agnivesa, chikitsa sthana, chapter no-19, shloka no-5, Varanasi, Chaukhambha Bharati Academy, Reprint-2015, Page no-558

7. Vangasena Samhitha, Chikitsakara Sangraha Vatavyadhi Nidana chapter S1-367,368,369. Prachya Prakashana, Varanasi. Page no-285

8. Ambikadatta Shastri, translator, Ayurvedatatvasandipika Hindi commentary on Sushruta Samhita, Part I, Chapter 17, verse no. 12, $2^{\text {nd }}$ Edition (reprint) Chaukhambha Sanskrit Sansthana, Varanasi, 2012; 94.

9. Shri Kashinatha Shastri and Shri Gorakhanatha Chaturvedi: Elaborated Vidyotini Hindi Commentary on Charak Samhita of Agnivesha, Part-II, Chikitsa Sthana, Chapter 28, verse no. 82, Reprint, Chaukhambha Bharati Academy, Varanasi, 2012; 792.

10. Shri Kashinatha Shastri and Shri Gorakhanatha Chaturvedi: Elaborated Vidyotini Hindi Commentary on Charak Samhita of Agnivesha, Part-II, Chikitsa Sthana, Chapter 28, verse no. 110, Reprint Year, Chaukhambha Bharati Academy, Varanasi, 2012; 797.

\section{Source of Support: Nil Conflict of Interest: None Declared}

How to cite this URL: Kavita et al: Pain Management In Katishoola: A Case Study. International Ayurvedic Medical Journal \{online\} 2021 \{cited November 2021\} Available from: http://www.iamj.in/posts/images/upload/2909_2913.pdf 